\title{
RBEP
}

\section{Imagem feminina e maternidade: o concurso de robustez infantil em São Paulo (1928)*}

Jane Soares de Almeida

\section{Resumo}

Analisa a realização de um concurso de robustez infantil em São Paulo em 1928 e relatado na revista O Brasil de Amanhã. O concurso, pela via do discurso oficial vigente, mostrava intenções igualitárias ao aceitar entre os concorrentes as crianças de todas as raças e sexos, desde que fossem robustas, saudáveis e seguissem os padrões de desenvolvimento físico e mental exigido. Inseria, ao mesmo tempo, uma visão de maternidade dedicada a alocar às mães a responsabilidade pela saúde e bem-estar de seus filhos, construindo uma imagética social voltada para o desempenho do papel materno e a nobreza dessa missão.

Palavras-chave: robustez infantil, maternidade, imagem feminina.

* Artigo baseado em trabalho apresentado na XVII Reunião Anual da ANPEd, Caxambu, 2004, GT História da Educação.

\section{Abstract}

Feminine image and maternity: the child robustness contest in São Paulo (1928)

The work analyzes a child robustness contest in São Paulo, in 1928, reported in the magazine O Brasil de Amanhã. The contest, officially speaking, showed egalitarian intentions by accepting children of all races and sexes as long as they were robust, healthy and followed the standards of demanded 
physical and mental development. It inserted, at the same time, a vision of maternity dedicated to give to the mothers the responsibility for the health and well being of their children, building a social image directed towards the performance of the maternal role and the nobility of this mission.

Keywords: child robustness; maternity; feminine image.

\section{Introdução}

No livro La mujer fragmentada: histórias de um signo, que recebeu o Prêmio Casa de las Américas de 1994, Lucia Guerra lembra que entre os astecas havia uma simbolização entre esquerda e direita equivalente a uma dicotomia entre o bem e o mal, a força e a fragilidade, a potência e a impotência. Nas suas práticas homeopáticas encontraram-se registros de fatos macabros segundo os quais os malfeitores roubavam da tumba de uma mulher morta durante o parto o seu braço esquerdo, com a finalidade de utilizá-lo como amuleto para imobilizar os donos de algum lugar que fossem assaltar e os colocar em estado de inconsciência. O braço teria o poder de conferir aos assaltantes a invisibilidade e tornar as vítimas indefesas contra seus malefícios (Guerra, 1995, p. 11). Entre esse povo o parto era um ritual diferenciado. Quando nascia um menino as parteiras recitavam a oração:

Meu filho amado, esta casa onde nascestes não é senão um ninho, uma pousada aonde chegaste, é tua saída do mundo, aqui brotas e floresces, aqui te separas de tua mãe, tua própria terra está em outra parte, é o campo onde se guerreia e teu ofício será dar de beber ao sol o sangue de teus inimigos e dar de comer à terra os corpos de teus inimigos (Guerra, 1995, p. 15, tradução adaptada).

Para a menina a oração profetizava um destino de servidão:

Filha minha, viestes a este mundo enviada por nosso senhor que está em todo lugar, viestes a um lugar de cansaço, de trabalho e de servidão, onde faz frio e vento. Tu haverás de estar dentro de casa como o coração dentro do corpo, não deverás sair de tua casa, não terás o costume de ir a nenhuma parte, deverás ser a cinza com que se cobre o fogo do lar, deverás ser as brasas onde se colocam as panelas, aqui deverás trabalhar, teu ofício será trazer água e moer o milho, aqui haverás de suar sobre as cinzas e o lar. (Guerra, 1995, p. 16, tradução adaptada).

Portanto, desde tempos antigos, eram evidentes as destinações diferenciadas para homens e mulheres: enquanto para os meninos a casa era um espaço transitório, para as meninas era o espaço perpétuo. Se para os primeiros se aspirava às glórias públicas, para aquelas se exigia a confinação doméstica.

Na tradição cristã existe uma forte oposição entre direita e esquerda que simboliza o bem e o mal, como, por exemplo, os dois ladrões ladeando Cristo no Calvário, que pode ter uma analogia com as práticas dos astecas do roubo do braço esquerdo da mulher morta no parto e a simbolização 
${ }^{1}$ Ginzburg (1989, p. 143) aborda as possibilidades de se recriar o passado através de fragmentos do cotidiano de personagens comuns, demonstrando uma visão diferenciada de se fazer a História, não mais aquela vista pela ótica dos vencedores. O autor refere-se ao paradigma que emergiu no século 19, ainda não teorizado explicitamente, e que pode "ajudar a sair dos incômodos da contraposição entre racionalismo e irracionalismo", naquilo a que denominou um saber indiciário. feminina. O fato é que o mito de Eva como aliada da serpente e seu papel na expulsão de Adão do Paraíso têm marcado a imagem feminina na Sociedade Cristã, que, ao longo dos séculos, tem construído uma imagem de mulher que se perpetua aos dias atuais, tal a força da permanência das mentalidades.

A partir desse ponto de vista, podemos considerar os liames propostos com os símbolos culturais em cada sociedade. A cultura estabelece conexões com vários aspectos da prática social: a vida cotidiana, a religião, a saúde, a economia, a política, a festa, os rituais, a educação e as relações entre os sexos, o que configura as interfaces do pluralismo na convivência entre os seres humanos. Nesse universo entrópico convivem as questões ligadas à subjetividade, ao sonho, à magia, às crenças e às representações simbólicas. Aí também se enquadram simbologias, nas quais as referentes ao sexo feminino emergem como categorizações distintas do mundo masculino, sendo vistas como portadoras de diferenças relacionais. O olhar dominante, no exercício das relações de poder, também é passível de atribuir defeitos e qualidades nas suas relações de alteridade e, dependendo da expectativa acerca da conduta considerada certa ou desviante, reprime e castiga com a mesma intensidade com a qual cria um esquema de simbologias acerca dessa alteridade.

Esta pode estar na contravenção das expectativas que o segmento dominante elaborou para o desempenho de papéis, sejam eles de natureza sexual, religiosa ou educativa, quando não se alinham com suas normas e regras de conduta. Esse olhar revela - como traços essenciais da alteridade daqueles que estão em situação de dominados - fragmentos imperfeitos que não são reveladores da profundidade e do pluralismo de sua cultura. No entanto, esses segmentos, muitas vezes reduzidos ao silêncio, possuem formas próprias de se expressar através de tradições, costumes religiosos ou profanos, escritos íntimos, reveladores do sentido da História, encobertos em sinais e revelados nos contornos mágicos dos mitos. ${ }^{1}$

No plano simbólico, a imagem feminina sempre foi associada ao cuidado, à maternagem e ao desprendimento. No campo da religiosidade, o catolicismo foi emblemático ao imbricar com a figura feminina os contornos sacralizados da aproximação com o arquétipo da Virgem. Nessa visão, não desprovida de objetivos socioculturais, a imagem materna aglutina o duplo simbolismo da mulher-mãe. Essa imagética tem o poder de transitar no mundo social, e sua duplicidade incorpora a figura redentora, mantenedora, transmissora e veiculadora da moralidade, unificadora da família, disseminadora, no ambiente sagrado do lar, dos hábitos e costumes de uma sociedade que se quer sadia, educada e organizada. Como instituição normatizadora e disciplinadora de corpos e almas, a Igreja católica associou a figura da mulher santa, feita à imagem de Maria, à pureza de corpo e espírito, enquanto a mulher desviante, transgressora, principalmente a prostituída, seria ligada à maldade, à perfídia, ao pecado e à decadência. Se a primeira é o espírito e a santidade, a segunda é carnal e pecadora, levando os homens à corrupção do caráter e do corpo. No entanto, ambas deveriam ser submissas e dependentes, pois a ordenação social assim o exige, e a 
ordem natural das coisas não deve ser questionada por aquelas que são as destinatárias de um processo de controle ideológico altamente repressor quanto à sexualidade.

No Brasil dos anos 20/30 do século 20, a corrente higienista se apropriou dessa imagética e transformou a mulher na principal responsável pela saúde dos filhos, e a maternidade passou a ser, além de uma aspiração individual e familiar, uma meta dos responsáveis pelas políticas públicas de saúde e educação, o que se configura, em última análise, um esquema simbólico de poder. A idéia de sexo para a mulher honrada estava intimamente ligada ao corpo assexuado. A mulher não precisaria sentir prazer no intercurso sexual e de preferência deveria manter a castidade, mesmo no casamento. A forma de preservar essa castidade seria relacionar-se sexualmente apenas para a procriação, evitando-se os excessos sexuais que causariam dano à saúde e à vida espiritual feminina. O desejo e o prazer eram reservados ao homem, o qual, segundo o discurso médico, era biologicamente voltado para a essência carnal por conta da virilidade. Impunha-se na vida social a necessidade sempre presente de manter as mulheres ao abrigo das injunções da vida pública e seus perigos, o que indiretamente poderia atingir os filhos. Isso tinha em vista, principalmente, a preservação da ordem vigente, e a educação oferecida às meninas e moças não poderia ultrapassar as fronteiras do doméstico e do socialmente permitido.

No Brasil, a ideologia de caráter religioso regrou a sexualidade da mulher e do casal, perpassando toda a vida social do século 19 e estendendose ao século 20, sendo veiculada na sociedade, na família e na educação. Nas escolas, as moças eram instruídas quanto à importância da castidade e da pureza; na Igreja deveriam confessar ao padre quaisquer pensamentos ditos impuros que porventura tivessem quanto ao sexo; na família se impediria toda e qualquer manifestação voltada para explorar ou exercer a sexualidade, embora houvesse transgressões que costumavam ser severamente punidas.

Nos anos finais do século 19, as mulheres, de acordo com as premissas do Positivismo, corrente que havia tomado corpo no País e sido assimilada pelas mentes ilustradas da época, eram vistas como seres dotados de atributos de pureza e doçura, responsáveis pela preservação da família e da moral cristã, mães generosas, espíritos de sacrifício, salvadoras da pátria, o que as colocava como responsáveis por toda a beleza e bondade que deveriam impregnar a vida social. Mesmo tendo introduzido um avanço em relação aos séculos anteriores, onde o mistério e as crendices herdadas da Idade Média ainda influíam nessas representações, o fato é que os positivistas, ao adotarem os modelos de domesticidade e espírito de sacrifício, foram determinantes para a desclassificação social da mulher. O discurso da pureza feminina e das suas qualidades morais armava-se de ambigüidades e prestava-se admiravelmente bem para referendar o mito da inferioridade biológica que vinha impregnando também o discurso dos evolucionistas através da idéias spencerianas. Esses princípios "serviram tanto para preservar os estereótipos da feminilidade instituídos, e, conseqüentemente, justificar a exclusão da mulher dos espaços masculinos de atuação social, quanto 
para defender seu direito de cidadania e de participação em igualdade de condições com os homens" (Rago, 1991, p. 149).

O imaginário social valorizava principalmente a mulher como mãe e esposa abnegada, para quem o lar era o altar no qual depositava sua esperança de felicidade, sendo o casamento e a maternidade suas únicas aspirações. Era ela também a primeira educadora da infância, sustentáculo da família e da Pátria. A procriação era o objetivo de sua vida, e para esse fim as educavam desde a infância. Na reconfiguração da sociedade que se desejava progressista e esclarecida, com o potencial de regeneração nacional, havia a crença na maternidade e sua função domesticadora: a mãe cuida, ampara, protege, ama e educa. Essa crença impregnou a imagética pósrepublicana e, juntamente com as aspirações de unidade política e a proliferação de um discurso alvissareiro sobre a educação, colocou nas mãos femininas a responsabilidade de guiar e higienizar a infância e moralizar os costumes. A figura da mulher-mãe que redimia e encaminhava para uma vida de utilidade e sucesso seria esculpida em prosa e verso. Nessa visão se construiu a tessitura mulher-mãe-educadora, aquela que defendia o lar da nocividade que vinha da rua e, como educadora, iluminava a infância na senda do saber e da moralidade. A professora, qual mãe amorosa, também estaria debruçada sobre as frágeis crianças a serem cuidadas, orientadas e transformadas por dedos que possuíam a capacidade natural de desenhar destinos e acalentar esperanças, coadjuvantes inspiradas de uma sociedade que se erigia sob os auspícios do desenvolvimento econômico e precisava inserir mudanças positivas num quadro social caótico e ainda atrelado aos resquícios coloniais.

Os anos iniciais do século 20 iriam ultrapassar, em parte, as teorias das diferenças biológicas propostas pelo Positivismo no século 19. Porém, essas diferenças vinham ao encontro de uma idéia de sociedade que necessitava da presença feminina, ao mesmo tempo em que serviam para referendar a ocupação do espaço público pelos homens, segregando-se as mulheres nos limites do privado e reservando a elas o cuidado com os filhos, que deveriam ser depositários dos seus ensinamentos morais.

Apesar de reforçar o discurso de desigualdade entre os sexos e incorporar a idéia da inferioridade feminina em alguns aspectos, os formadores de opinião no século 20 advogariam instrução igual para homens e mulheres, embora mantendo as diferenças quanto ao desempenho dos papéis sexuais. A educação que se pretendia igual para os dois sexos na realidade diferenciava-se nos seus objetivos, pois, de acordo com o ideário social, o trabalho intelectual não devia fatigar o sexo feminino nem se constituir um risco a uma constituição que se afirmava frágil e nervosa. O fim último da educação era preparar a mulher para o serviço doméstico e o cuidado com o marido e os filhos, não se cogitando que viesse a desempenhar uma profissão assalariada. A mulher educada dentro dessas aspirações masculinas seria uma companhia mais agradável para o homem que transitava regularmente no espaço urbano, diferentemente da prática do período colonial, com seu recolhimento e distanciamento do espaço da sociabilidade. Essa mesma mulher teria no desempenho de seu papel de mãe sua máxima 
aspiração individual, e era no incentivo às virtudes e talentos maternos para se preservar as futuras gerações de brasileiros que se concentravam os esforços do Estado. Nessa idéia de educação associada à saúde, nos anos 20 do século 20, setores da intelectualidade se aliariam aos médicos e higienistas:

\begin{abstract}
O movimento protagonizado por médicos e higienistas em favor da reforma dos serviços de saúde tem inúmeros pontos de contato com o promovido por amplos setores da intelectualidade em favor da "causa educacional", nos anos 20. Não apenas porque ambos tinham como objetivos comuns a reforma dos serviços públicos, a modernização do país e a ampliação de possibilidades de participação política e de atuação profissional; mas, principalmente, porque saúde e educação se apresentavam para seus agentes como questões indissociáveis (Carvalho, 2001, p. 305)
\end{abstract}

A necessidade da educação feminina firmava-se na convicção de que educação e saúde eram um binômio indissolúvel, e nenhuma medida profilática seria eficaz sem os hábitos higiênicos desenvolvidos pela educação, havendo um movimento no sentido de instruir as jovens em nível primário e secundário, assim como incentivar seu ingresso no magistério de crianças. No entanto, devido à separação dos papéis sexuais que reservavam à mulher tradicionalmente apenas a função de esposa e mãe, dificilmente as moças chegavam a cursar o ensino superior ou desempenhar profissões de maior relevo social. A responsabilidade feminina nunca deveria transpor as fronteiras do lar nem ser objeto de trabalho assalariado. O trabalho somente poderia ser lícito se significasse cuidar de alguém, doarse com nobreza e ressignação e servir com submissão, qualidades inerentes às mulheres, premissas com as quais também se afinavam profissões ligadas à saúde, como enfermeira ou parteira.

O pressuposto da inferioridade biológica e intelectual das mulheres também levou os seguidores do Positivismo, empenhados na instauração da Ordem e do Progresso, a considerar natural o posicionamento dos homens no poder baseando-se nas diferenças entre os sexos, o que justificava a subordinação e opressão feminina e seu afastamento da esfera pública. Os sofismas positivistas foram fortalecidos no movimento higienista brasileiro quando os médicos sanitaristas a serviço do Estado decidiram, em nome do progresso e das necessidades profiláticas dos crescentes centros urbanos que se alicerçavam na antiga colônia, principalmente São Paulo e Rio de Janeiro, reservar à mulher a responsabilidade pela higiene doméstica e os cuidados com a saúde da prole. A herança cultural revelou-se extremamente eficaz, e décadas transcorreram até que se conseguisse passar ao seu questionamento, embora não sua eliminação, já que as formulações higienistas continuaram encontrando respaldo em diversos setores sociais, entre o sexo masculino e mesmo entre as próprias mulheres, para seguir justificando as mais variadas formas de opressão.

O discurso médico sanitarista do século 19, que impôs a ideologia do amor materno, plenamente apoiado pela Igreja católica, representava as mulheres como as guardiãs do lar cristão, depositárias das esperanças da raça e responsáveis em formar o corpo e a alma dos futuros cidadãos: 
[...] de um lado, expunham-se as recompensas da carreira do casamento e da maternidade: uma relação mais sólida entre os membros da família, o amor do marido, a mulher elevada à condição de figura central do seu território. De outro, as punições: sentimento de culpa, frustração, os castigos da natureza contrariada, os perigos físicos da não-procriação ou da retenção do leite, no caso das mães, etc. (Rago, 1991, p. 80).

Disciplinada pelos homens, a educação das mulheres continuou um prolongamento da educação familiar. As poucas jovens que estudavam, enquanto o faziam, aguardavam o casamento, e o estudo configurava-se como uma preparação para o que realmente importava em suas vidas: casar e ter filhos. Essas mulheres, de acordo com o imaginário que se forjava nesses tempos pós-republicanos, não eram mais as procriadoras incultas, mas as futuras esposas educadas, conhecedoras das necessidades do marido e dos filhos, alicerces da moral e dos costumes, fiéis guardiãs do lar cristão e patriótico. Romper com tais estruturas (e sempre houve quem o fizesse) significava o degredo ou a condenação social. Portanto, o poder não se nivelou eqüitativamente e sequer significou a liberação das mulheres, mas apenas humanizou-se ao consentir na sua instrução.

Ter filhos e criá-los condignamente, eis o princípio norteador do significado de ser mulher e ser mãe. Essas duas ações se confundem e são objetos do mesmo discurso; aliás, ser mãe supera o ser mulher, não são princípios interdependentes nem excludentes, mas se configuram num todo desejável e passível de completar e suprir as lacunas das práticas sociais. Repousa na mãe a responsabilidade pela saúde dos filhos e, conseqüentemente, pela projeção da Pátria no cenário internacional, pois nenhum país pode ser forte e soberano se seus cidadãos não possuem o perfil idealizado da raça que vai construir a nação. Herdeiros de um futuro que se delineia promissor na visão política dos anos de 1920/30, os brasileiros devem ser fortes, saudáveis, possuir hábitos higiênicos e, acima de tudo, ser robustos. No cumprimento dessa aspiração social, que é também eminentemente política, não se poderão distinguir os sexos, as raças, as classes sociais. Pelo menos é isso que se depreende da simbologia implícita nos discursos proferidos e relatados nos vários jornais que circulavam na capital paulista, posteriormente transcritos em O Brasil de Amanhã: Revista de Divulgação e Higiene, acerca do Concurso de Robustez Infantil realizado em 25 de janeiro de 1928. Era uma forma de comemorar com brilho e patriotismo o aniversário da cidade de São Paulo, dar exemplos cívicos ao País e ao mundo, era alinhar-se às aspirações de uma raça forte comandando uma nação que iria ser soberana num futuro que se anunciava alvissareiro.

Porém, quase trinta anos após a República, a educação ainda não havia se consolidado no acalentado sonho liberal republicano, a população miserável não tinha as condições sequer razoáveis de sobrevivência, mas o discurso sanitarista apostava na força propulsora da ordem e do progresso: a saúde aliada à educação. Mais uma face do discurso liberal que se sobrepunha e fazia prevalecer as aspirações republicanas, mesmo eivado de subjetivismo e distante da realidade socioeconômica e cultural do Brasil. 


\section{Mães cuidadosas, filhos saudáveis: o concurso de robustez infantil}

Os anos de 1920 foram palco de uma proliferação discursiva que apontava para os imensos males advindos do contágio entre raças diferentes; ou seja, qualquer tentativa de mestiçagem com negros, índios e mulatos, etnias não pertencentes à considerada raça branca, não era bem recebida; pelo contrário, era inominável que houvesse sequer o esboço de um movimento nesse sentido. Isso porque era unânime a idéia da degradação moral e degeneração racial que esse cruzamento desencadearia:

As trilhas ideológicas perfiladas pelos eugenistas, como as teorias de Galton, de Gobineau, de Gustave Le Bon, de Renan e de Taine, entre outros; a fundação da Sociedade Eugênica de São Paulo, à qual se filiaram personalidades até então insuspeitas, como Fernando de Azevedo, as conexões entre lideranças empresariais, políticas e médicas em torno dos ideais eugênicos, que propunham estreita associação entre educação moral, higiene e hereditariedade, manifesta em propostas tais como regulamentação dos casamentos, da imigração, da prostituição e em maior controle psiquiátrico da loucura (Adorno, 1994, p. 15).

A corrente racista entenderia como verdadeira a tese de que a mistura de vários sangues ou raças degeneraria os povos, destacando-se o arianismo. Com isso se dividia a raça humana em povos superiores e inferiores, e estes últimos seriam incivilizáveis e impossibilitados de progredir; portanto, qualquer contágio racial não era apenas sinônimo de um cadinho biológico, mas também sintoma de subdesenvolvimento econômico e ausência de civilização. No entanto, há que se entender que nem sempre essas teorias eram típicas das questões raciais; de uma maneira geral, os pobres também se enquadravam nesse esquema de periculosidade, o que independia da raça.

Na luta contra o inimigo comum, a doença, que espalhava suas garras predatórias no amontoamento urbano fétido das primeiras décadas do século 20, os médicos e as autoridades impunham como parte das políticas de educação e saúde a higienização dos costumes, deplorando práticas consideradas maléficas ao bem-estar e ao desenvolvimento, entre elas a ausência de higiene das mães e das crianças, causa de mortalidade e gastos governamentais. Havia, pois, que motivar a profilaxia e se alinhar com o saneamento dos corpos e das famílias, protegendo a maternidade e, através dela, a infância. O melhor caminho seria motivar, convencer e premiar. Nessa cruzada higiênica, a colaboração das mães e das educadoras sanitárias, preparadas para esse fim, era incontestável. E que melhor recurso de motivação e atenção pública do que um concurso com prêmios, discursos laudatórios, divulgado na imprensa e aplaudido pela população?

O Brasil de Amanhã, sob direção do Dr. F. Figueira de Mello, anunciou em sua publicação número cinco os resultados do Grande Concurso de Robustez Infantil, que aconteceu no dia 25 de janeiro de 1928 no anfiteatro do Jardim de Infância situado na Praça da República. O concurso, de iniciativa da Diretoria Geral do Serviço Sanitário, tinha sido organizado pela Inspetoria de Educação Sanitária, dirigido pelo Dr. Waldomiro de Oliveira. 
Com o chamativo título "Em defesa da raça - a Nação caminha pelos pés da criança", o diretor da revista apresentou os resultados colhidos e dedicou o concurso ao problema da infância no Brasil, visando principalmente o reerguimento físico e moral da raça através do melhoramento de sua inteligência. No artigo, defendeu que um país não poderia ser grande se a saúde do povo não fosse objetivo de atenção dos governantes, dado que todos os demais problemas decorriam inevitavelmente do imperativo sanitário. Como primeiro passo para a resolução da meta de possuir uma população saudável, o principal ponto a ser atingido era a instrução das mães, que "formarão a consciência sanitária do paiz, porque passarão a pôr em prática o que aprenderam e educarão seus filhos dentro das normas intelligentes e benéficas" (Mello, 1928, p. 2).

Para a instrução das mães, os centros de saúde estabeleceriam notável importância e deveriam ser multiplicados por todo o Estado de São Paulo. Nos centros de saúde, a figura feminina de especial relevância seria a das educadoras sanitárias, mensageiras das noções de higiene às escolas e aos lares:

Dedicadas e operosas, arrostam as tormentas, os mil e um aborrecimentos de cada dia, desbastando nas classes proletárias a rude ignorância que as torna hostis a toda e qualquer iniciativa que atente contra a rotina. O Concurso de Robustez Infantil demonstrou até que ponto é lícito esperar das educadoras uma profunda influência modificadora do atual estado de coisas. Incumbidas de ministrar às genitoras os conhecimentos indispensáveis à formação de uma geração robusta, integrada em novos moldes de conduta sanitária, excederam-se a si mesmas em dedicação apaixonada pela causa nobilitante que abraçaram (Mello, 1928, p. 3).

O editor da revista terminou seu artigo exortando a iniciativa do concurso e o papel decisivo das mães na saúde de seus filhos, afirmando que "sobre os pés das crianças é que o Brasil ascenderá ao apogeu da glória e da grandeza" (Mello, 1928, p. 4). Em seguida há uma montagem fotográfica com as fotos das nove crianças classificadas no concurso.

O concurso tinha como bases gerais a admissão de crianças de um a três anos de idade que estivessem matriculadas nos Centros de Saúde, na seção de proteção à infância, há mais de três meses e com freqüência assídua ao serviço. A matrícula seria realizada sob a forma de uma lista de concorrentes apresentada pelos médicos assistentes, após preenchimento dos seguintes itens: nome, idade, cor, nacionalidade, nome do pai e da mãe, residência e profissão, além do número inscrito no serviço de saúde. Após outros quesitos para regulamentação do concurso, o artigo 7o determinava que seriam avaliadas as crianças matriculadas nos vários centros de saúde da capital, por meio de escrutínio secreto (O Brasil de Amanhã, 1928, art. 11, p. 4). Todos os inscritos seriam contemplados com um certificado de robustez infantil, e o primeiro prêmio constaria de Rs $400 \$ 000$ (quatrocentos mil-réis), o segundo, de Rs 200\$000 (duzentos mil-réis) e o terceiro e quarto prêmios seriam de Rs $100 \$ 000$ (cem mil-réis). Além desses, haveria mais dois prêmios de assiduidade aos serviços, uma dúzia de fotografias de cada criança premiada e uma medalha de ouro para o primeiro lugar, a ser ofertada pelo jornal A Gazeta. 
A isso se acrescentava uma listagem completa do exame médico da criança, desde o período pré-natal aos atuais anos de vida, incluindo amamentação materna ou por ama alugada, o desmame, estigmas hereditários, testes de moléstias, etc. A criança não deveria ser gorda, mas robusta, não importava seu sexo ou sua cor, eram todas consideradas brasileiras, filhas legítimas de uma terra fértil e produtiva, que tinha um destino grandioso e um porvir para o qual estavam voltados os olhos das demais nações.

\section{As expectativas quanto ao concurso}

Os jornais em circulação na capital, como Folha da Noite, Jornal do Commercio, Tribuna, Diário da Noite, Folha da Noite, Correio Paulistano, São Paulo Jornal, A Gazeta, A Folha da Manhã, O Estado de S. Paulo, citados na revista, haviam dado grande destaque ao concurso, uma obra de patriotismo e fé, com reportagens nas quais se destacaria sua importância na criação de uma "raça mais forte, já inteiramente livre de taras ou prejuízos orgânicos" (O Brasil de Amanhã, 1928, p. 10).

Os jornais defenderam apaixonadamente os serviços de saúde públicos e o trabalho dos higienistas, esforçados e patriotas, voltados para um povo que muitas vezes não compreendia suas iniciativas. A mentalidade cosmopolita do paulistano, agravada pela crise da água, a promiscuidade nas habitações coletivas, a miséria do proletariado, o pauperismo devido à concorrência, a deseducação sanitária, "mal congênito entre os naturais do país" (O Brasil de Amanhã, 1928, p. 13), tornavam essa iniciativa ainda mais difícil por parte dos responsáveis pela saúde da população. Se os médicos sanitaristas eram de suma importância no projeto de uma nação limpa, culta e civilizada, a revista observa que as mulheres têm sido extraordinariamente cooperativas nessa importante missão, na qual se destaca principalmente o papel das mães, das professoras e das educadoras sanitárias, formadas especialmente para levar a mensagem de uma vida sadia à população.

O jornal A Gazeta rejeita a noção difundida no país de que antes de divulgar os compêndios de higiene e as normas de preservação da saúde, há que se ensinar os brasileiros a lerem, afirmando que isso é uma inverdade: "o que há é um desvio intelectual, vício adquirido na versatilidade com que espíritos imponderados dispersam tempo e inteligência no manuseio de coisas inúteis. É preciso desenvolver no País o gosto pelas leituras sérias e úteis" ( $O$ Brasil de Amanhã, 1928, p. 16).

A Folha da Manhã louva especialmente as educadoras sanitárias, incansáveis em desenvolver na "rudimentar inteligência" das mães da classe operária o conhecimento das normas de higiene na manutenção da saúde de seus filhos. O Estado de $S$. Paulo analisa o concurso como um meio de despertar a atenção de todas as classes para as obras sanitárias e sua propaganda, "condição única pela qual teremos amanhã uma raça bem proporcionada dentro dos moldes da moderna eugenia"(O Brasil de Amanhã, 1928, p. 18). 


\section{Louras e morenas. E de cor, também: crianças vendendo saúde}

A eugenia, vista como ciência que estuda a reprodução, o melhoramento e a saúde da raça humana e as condições mais propícias para a influência da medicina, reverenciada nos anos 20 do século passado, emergia na história do País com legitimidade garantida pelos estudiosos europeus e norte-americanos. A proliferação discursiva amparada nos princípios eugênicos iria se afirmar como uma corrente que condenava "os contágios entre pessoas de etnias diferentes como fonte de degeneração racial e de degradação moral". (Adorno, 1994, p. 15). A corrente eugênica se configuraria numa cruzada civilizatória, e seus representantes,

[...] na sua missão, ocuparam todos os espaços possíveis: as academias médicas, as escolas, as delegacias de polícia, os tribunais de justiça, estabelecendo uma verdadeira rede de solidariedade entre discursos, instituições e personagens, entre estes o médico, o pedagogo, o jurista, os agentes de controle social repressivo, a dona de casa, o pai preocupado com o destino de sua prole. [...] E, antes de tudo, o investimento dos eugenistas no aparelho escolar, mais propriamente na formação de sujeitos escolarizados, moralizados, eugenizados, por fim civilizados. Tudo sugere o quão avançados se encontravam, àquela época, os rumos de nossa marcha civilizatória! (Adorno, 1994, p. 15-16).

No entanto, nas fotos estampadas na revista com as crianças selecionadas para participar do concurso, há bebês brancos e negros, há meninos e meninas de cabelos louros, pele clara e olhos azuis, denunciando sua origem européia, e há meninos negros e mulatos, resultantes da exuberante miscigenação racial do País desde os primeiros tempos da colonização. A diversidade populacional não permitiria divisões étnicas no concurso - asseguravam seus organizadores -, e a condição precípua de participar estava na boa saúde, na robustez, o patrimônio biológico que a Nação queria fortalecer.

Na seleção dos inscritos, coube às educadoras sanitárias a tarefa de buscar nos fichários e fazer uma seleção prévia para ser apresentada aos médicos pediatras. Uma vez escolhidas as crianças, as mães foram notificadas, e uma comissão nomeada com membros representativos da sociedade paulista procedeu a um trabalho final do processo de inscrição, tendo selecionado 129 crianças julgadas aptas a concorrer aos prêmios. O concurso foi marcado para as 16 horas, no anfiteatro do Jardim da Infância:

[...] crianças por toda parte. Louras e morenas. E de cor, também. Crianças de carmin-natural, vendendo saúde. Crianças sorrindo, brincalhonas e crianças choramingando... Esplêndido espectaculo, que tonifica a alma e impressiona o coração! (Adorno, 1994, p. 31).

Para atingir o objetivo do progresso biológico defendido pela higiene e pela eugenia, estava explícita e latente a idéia de que educando a mãe nos modernos preceitos de preservação da saúde se poderia amparar a criança para que tivesse mocidade robusta, preparando a Nação para ser forte e vitoriosa. A mãe é a figura central no processo da higiene da infância; de 
nada valeriam os cuidados médicos e a boa alimentação se a criança não estivesse rodeada dos inteligentes cuidados maternos. Contrapõe-se, pois, à ignorância materna, a sua educação: esta é a chave-mestra contra a mortalidade, e nela reside a responsabilidade da preservação da vida desde a mais tenra idade. As mães devem ser as aliadas do Estado e dos sanitaristas, cerrando fileiras para proteger a saúde da infância. Amparando-se a mãe e instruindo-a durante e após a gestação é o segredo do Estado para construir uma nação perfeita.

A robustez infantil é apresentada, no sentido médico, com todos os caracteres de vitalidade equilibrada, funções harmônicas e órgãos perfeitos. Não é a gordura, como pensam os leigos, desconhecedores das práticas higiênicas, que é representada por uma distrofia farinácea com excesso de tecido adiposo; isso é anti-higiênico, pois predispõe ao desequilíbrio das funções internas e contribui para males de saúde. A criança paulista deve ser a mais robusta, mais sadia, rica e feliz. Para isso é necessária a parceria feliz e benéfica das mães, das professoras, das educadoras sanitárias, dos médicos, dos intelectuais, unidos todos numa cruzada patriótica em defesa da raça e da Pátria.

Após os discursos enaltecedores da iniciativa do concurso, foram premiados entre os concorrentes dois meninos e duas meninas. Nas fotos dos vencedores observa-se que todos os quatro podem ser situados como pertencentes à raça branca, de sobrenomes que denunciam a origem européia: $1^{\circ}$ lugar - Domingos Scalabrini; $2^{\circ}$ lugar - Ewely Bueno de Camargo; $3^{\circ}$ lugar - Nicolino Bounfiglioli; $4^{\circ}$ Lugar - Helena Wolpi. Sobre os concorrentes, o jornal Folha da Noite, de 26 de janeiro de 1928, assegura:

A maioria dos 129 concorrentes que tomaram parte do certamen de hontem - e que representava, como se sabe, o resultado d'uma seleção previamente feita - deu entrada nos diversos centros de saúde da cidade em petição de miséria orgânica, umas devido a enfermidades herdadas, ou adquiridas, outras devido a um regimen alimentar errado. Contemplando as photographias tiradas por occasião da entrada nos referidos centros, em que ellas pareciam, já, mais cadáveres do que viventes, e observando-as hontem, no amphitheatro do Jardim da Infância, onde se realisou o concurso, rindo e grulhando, ninguém diria que essas crianças eram as mesmas [...]. Essas 129 crianças, inscritas e seleccionadas entre as que freqüentam os centros de saúde, são outros tantos expoentes da raça forte e sadia de amanhã e com a qual o futuro do Brasil poderá contar para a grandeza inevitável do seu domínio victorioso na América (Adorno, 1994, p. 42).

O jornal Diário da Noite recorre ao texto da Convenção de Genebra sobre a Declaração dos Direitos da Criança, defendido e aprovado em 26 de setembro de 1924 na Liga das Nações, onde se afirma que a Humanidade deve às crianças o que de melhor se lhes possa dar, como um dever, sem considerar raças, nacionalidades ou crenças. Afirmam os articulistas que os cuidados com a infância devem ser prestados pelos centros de saúde, que educarão a todos, pais e filhos, na higiene, promovendo com isso combate aos casamentos sem exame médico prévio. A falta de cuidado com as gestantes, o hábito de não amamentar os filhos, uma dieta prejudicial e errada 
dos recém-nascidos, os maus hábitos herdados e adquiridos, a habitação anti-higiênica, a falta de assistência médica regular contribuem para os danos à saúde, para a fraqueza geradora da miséria e para a mortalidade infantil. Todos os jornais são unânimes em afirmar que é no cuidado com as crianças que se resume o futuro próspero do País; é no aperfeiçoamento das futuras gerações que se edifica a nacionalidade brasileira; portanto esses são atos de estrito patriotismo: "aperfeiçoemos a raça se não quisermos ser tragados pelo meio, na palavra pura de Euclydes da Cunha" (Adorno, 1994, p. 49).

Feitas as solenidades de praxe, voltariam as mães orgulhosas aos seus lares, com seus laureados rebentos. Meninos e meninas seriam contemplados com o emblema higienista e com o atestado da robustez, que lhes atribuía a difícil tarefa de promover o futuro da Nação; as crianças robustas e saudáveis, como depositárias das esperanças de crescimento e desenvolvimento, levariam o País na senda do progresso, não importando sua raça, seu sexo, sua cor. As educadoras sanitárias responsáveis pelo sucesso do certame são louvadas pelo amor ao próximo, patriotismo e abnegação; as professoras, os professores, os governantes e os médicos, por seu empenho patriótico em colaborar para o êxito do concurso. Mas seriam as mães as verdadeiras estrelas da festa, mulheres abnegadas que faziam sua vida girar em torno da vida de seus filhos, em cujas mãos o futuro do País estava garantido.

Os concursos de robustez infantil se tornariam extremamente concorridos durante algum tempo no território paulista e seriam imitados em outros Estados. Filhos e mães cuidadosas seriam premiados e teriam suas fotos estampadas nos diários que circulavam na capital paulista e, acima de tudo, eram exemplos a serem imitados. Não importava se a capital ainda convivia com a Roda dos Expostos, com a infância depauperada, com as epidemias e a mortalidade, principalmente entre os imigrantes pobres e a população negra. Por algum tempo se acalmariam os ânimos perante algum novo surto de febre, gripe ou cólera, e a opinião pública se emocionaria com tantas amenidades e promessas que se consolidariam num hipotético futuro. Outros concursos viriam, novos sonhos seriam edificados sobre as ilusões da República, e seus ideais de igualdade e democracia a iluminar o País no alvissareiro futuro em devir. E como sustentáculo dessa apoteose, a escola, templo do saber e da higiene, seria a panacéia para todos os males, em cujo esplendor a República seria consolidada e o Brasil triunfaria como Nação.

\section{Referências bibliográficas}

ADORNO, S. Prefácio. In: MARQUES, V. R. B. A medicalização da raça: médicos, educadores e discurso eugênico. Campinas: Ed. Unicamp, 1994.

CARVALHO, M. M. C. de. Quando a história da educação é a história da disciplina e da higienização das pessoas. In: FREITAS, M. C. de. (Org.). História social da infância no Brasil. São Paulo: Cortez, 2001. 
GINZBURG, C. Mitos, emblemas e sinais: morfologia e história. São Paulo: Companhia das Letras, 1989.

GUERRA, L. La mujer fragmentada: historias de un signo. Santiago: Editorial Cuarto Propio, 1995.

MARQUES, V. R. B. A medicalização da raça: médicos, educadores e discurso eugênico. Campinas: Ed. Unicamp, 1994.

MELLO, F. Figueira de. Em defeza da raça - a nação caminha pelos pés da criança. O Brasil de amanhã. Revista de divulgação de hygiene, São Paulo, n. 5, 1928.

O BRASIL DE AMANHÃ: Revista de divulgação de hygiene. São Paulo, n. $5,1928$.

RAGO, M. Os prazeres da noite: prostituição e códigos da sexualidade feminina em São Paulo (1890-1930). Rio de Janeiro: Paz e Terra, 1991.

ROCHA, H. H. P. A higienização dos costumes: educação escolar e saúde no projeto do Instituto de Hygiene de São Paulo (1918-1925). São Paulo: Mercado de Letras, 2003.

Doutora em História e Filosofia da Educação pela Universidade de São Paulo (USP); pós-doutora pela Harvard University, Estados Unidos; pósdoutora pela Universidade Autônoma de Barcelona, Espanha; pesquisadora do CNPq em "Produtividade da pesquisa"; professora titular do Programa de Pós-Graduação em Educação pela Universidade Metodista de São Paulo. janeal@vivax.com.br jane.almeida@pesquisadorcnpq.br

Recebido em 19 de outubro de 2006.

Aprovado em 3 de novembro de 2006. 